UDC 624.04, 519.853

\title{
PARAMETRIC OPTIMIZATION OF STEEL LATTICE PORTAL FRAME WITH CHS STRUCTURAL MEMBERS
}

\author{
V. V. Yurchenko ${ }^{1}$, \\ Doctor of Technical Science, Associate Professor \\ I. D. Peleshko ${ }^{2}$, \\ Candidate of Technical Science, Associate Professor \\ ${ }^{1}$ Kyiv National University of Construction and Architecture \\ Povitroflotskyj av., 31, Kyiv, 03680 \\ ${ }^{2}$ Lviv Polytechnic National University \\ St. Bandery str., 12, Lviv, 79013
}

DOI: $10.32347 / 2410-2547.2021 .107 .45-74$

The paper has proposed a mathematical model for parametric optimization problem of the steel lattice portal frame. The design variable vector includes geometrical parameters of the structure (node coordinates), as well as cross-sectional dimensions of the structural members. The system of constraints covers load-carrying capacities constraints formulated for all design sections of structural members of the steel structure subjected to all ultimate load case combinations. The displacements constraints formulated for the specified nodes of the steel structure subjected to all serviceability load case combinations have been also included into the system of constraints. Additional requirements in the form of constraints on lower and upper values of the design variables, constraints on permissible minimal thicknesses, constraints on permissible maximum diameter-to-thickness ratio for the structural members with circle hollow sections, as well as the conditions for designing gusset-less welded joints between structural members with circle hollow sections have been also considered in the scope of the mathematical model. The method of the objective function gradient projection onto the active constraints surface with simultaneous correction of the constraints violations has been used to solve the formulated parametric optimization problem. New optimal layouts of the steel lattice portal frame by the criterion of the minimum weight, as well as minimum costs on manufacturing and erection have been presented.

Keywords: optimization, steel lattice frame, nonlinear programming, strength, buckling, stiffness, gradient projection method, finite element method, numerical algorithm.

Introduction. Over the past 50 years, numerical optimization and the finite element method have individually made significant advances and have together been developed to make possible the emergence of structural optimization as a potential design tool. In recent years, great efforts have been also devoted to integrate optimization procedures into the CAD facilities. With these new developments, lots of computer packages are now able to solve relatively complicated industrial design problems using different structural optimization techniques.

Applied optimum design problems for bar structures in some cases are formulated as parametric optimization problems, namely as searching problems for unknown structural parameters, which provide an extreme value of the specified purpose function in the feasible region defined by the specified constraints [1]. In this case, structural optimization is performed by variation of the structural parameters when the structural topology, cross-section types and

(C) Yurchenko V.V., Peleshko I.D. 
node type connections of the bars, the support conditions of the bar system, as well as loading patterns and load design values are prescribed and constants [2].

Kibkalo et al. in the paper [3] formulated a parametric optimization problem for thin-walled bar structures and considered methods to solve them. The searching for the optimum solution has been performed by varying the structural parameters providing the required load-carrying capacity of structural members and the minimum value of manufacturing costs.

Serpik and Alekseytsev in the paper $[4,5]$ developed a methodology for the optimal design of normally operated steel frames considering material and social losses from the possible failure of structural members. A method for parametric optimization of steel frame systems during selection of rod crosssections and structure reliability levels has been developed. The optimization problem has been formulated as a structure manufacturing costs minimization problem taking into account costs on recover the damages caused by any material and social losses in the event of possible malfunctions and damage. Constraints on the strength, stiffness, and stability of the frame have been included into consideration. An iterative procedure for searching for optimum solution has been also proposed.

Serpik and Averin proposed a computational scheme for the optimal design of steel flat frames made of thin-walled rods with closed cross sections [6]. The structural member' total cost has been minimized by searching for the materials' grades and the rods' cross sections sizes on the variable parameters' discrete sets. Active constraints on the overall structural system's stability, local stability of the rods' walls, strength and stiffness have been taken into account.

Sergeyev et al. in the paper [7] formulated a parametric optimization problem with constraints on faultless operation probability of bar structures with random defects. The weight of the bar structures has been considered as the objective function. Initial global imperfections have been considered as small independent random variables distributed according to normal distribution law, as well as buckling load value has been also considered as a random variable.

The mathematical model of the parametric optimization problem of structures includes a set of design variables, an objective function, as well as constraints, which reflect generally non-linear dependences between them [8]. If the purpose function and constraints of the mathematical model are continuously differentiable functions, as well as the search space is smooth, then the parametric optimization problems are successfully solved using gradient projection non-linear methods [9]. The gradient projection methods operate with the first derivatives or gradients only both of the objective function and constraints. The methods are based on the iterative construction of such a sequence of the approximations of design variables that provides convergence to the optimum solution (optimum values of the structural parameters). Additionally, a sensitivity analysis is a useful optional feature that could be used in scope of the numerical algorithms developed based on the gradients methods $[10,11]$.

In this paper, steel lattice portal frame is considered as research object, which investigated for the searching for optimum parameters of the structural form. The 
following research tasks are formulated: to develop a mathematical model for parametric optimization of the considered steel structures taking into account load-carrying capacities and stiffness constraints; to propose a numerical algorithm for parametric optimization of the steel structures based on the gradient projection method; to confirm the validity of the optimum solutions obtained using the proposed methodology based on numerical examples.

\section{Problem formulation for parametric optimization of steel} structures. Let us consider a parametric optimization problem of a structure consisting of bar members. The problem statement can be performed taking into account the following assumptions widely used in structural mechanic problems: the material of the structure is ideal elastic; the bar structure is deformable linearly; external loadings applied to the structure are quasi-static.

Let us also formulate the following pre-conditions for calculation: cross-section types and dimensions of structural members are constant along member lengths; external loadings are applied to the structural members without eccentricities relating to the center of mass and shear center of its cross-sections; an additional restraining by stiffeners are provided in the design sections where point loads (reactions) applied with the exception of cross-section warping and local buckling of the cross-section elements; load-carrying capacity of the structural joints, splices and connections are provided by additional structural parameters do not covered by the considered parametric optimization problem.

A parametric optimization problem of the structure can be formulated as presented below: to find optimum values for geometrical parameters of the structure and member's cross-section dimensions, which provide the extreme value of the determined optimality criterion and satisfy all load-carrying capacities and stiffness requirements. We assume, that the structural topology, cross-section types and node type connections of the bars, the support conditions of the bar system, as well as loading and pre-stressing patterns are prescribed and constants.

The formulated parametric optimization problem can be considered integrally using the mathematical model in the form of the non-linear programming task including an objective function, a set of independent design variables and constraints, which reflect generally non-linear dependences between them. The validity of the mathematical model can be estimated by the compliance of its structure with the design code requirements.

The parametric optimization problem of steel structures can be stated in the following mathematical terms: to find unknown structural parameters $\vec{X}=\left\{X_{l}\right\}^{T}, \quad \imath=\overline{1, N_{X}} \quad\left(N_{X}\right.$ is the total number of the design variables), providing the least value of the determined objective function:

$$
f^{*}=f\left(\vec{X}^{*}\right)=\min _{\vec{X} \in \Im^{\prime}} f(\vec{X}),
$$

in a feasible region (search space) $\mathfrak{I}$ defined by the following system of constraints:

$$
\boldsymbol{\psi}(\vec{X})=\left\{\psi_{\kappa}(\vec{X})=0 \mid \kappa=\overline{1, N_{E C}}\right\}
$$




$$
\boldsymbol{\varphi}(\vec{X})=\left\{\phi_{\eta}(\vec{X}) \leq 0 \mid \eta=\overline{N_{E C}+1, N_{I C}}\right\} ;
$$

where $\vec{X}$ is the vector of the design variables (unknown structural parameters); $f, \psi_{\kappa}, \varphi_{\eta}$ are the continuous functions of the vector argument; $\vec{X}^{*}$ is the optimum solution or optimum point (the vector of optimum values of the structural parameters); $f^{*}$ is the optimum value of the optimum criterion (objective function); $N_{E C}$ is the number of constraints-equalities $\psi_{\kappa}(\vec{X})$, which define hyperplanes of the feasible solutions; $N_{I C}$ is the number of constraints-inequalities $\varphi_{\eta}(\vec{X})$, which define a feasible region in the design space $\mathfrak{I}$.

The vector of the design variables comprises of unknown geometrical parameters of the structure $\vec{X}_{G}=\left\{X_{G, \chi}\right\}^{T}, \chi=\overline{1, N_{X, G}}$, and unknown crosssectional dimensions of the structural members $\vec{X}_{C S}=\left\{X_{C S, \alpha}\right\}^{T}, \alpha=\overline{1, N_{X, C S}}$ :

$$
\vec{X}=\left\{\vec{X}_{G}, \vec{X}_{C S}\right\}^{T}=\left\{\left\{X_{G, \chi}\right\},\left\{X_{C S, \alpha}\right\}\right\}^{T} ;
$$

where $N_{X, G}$ is the total number of unknown node coordinates of the steel structure; $N_{X, C S}$ is the total number of unknown cross-sectional dimensions of the structural members, $N_{X, G}+N_{X, C S}=N_{X}$.

The specific technical-and-economic index (material weight, material cost, construction cost etc.) or another determined indicator can be considered as the objective function Eq. (1.1) taking into account the ability to formulate its analytical expression as a function of design variables $\vec{X}$.

Load-carrying capacities constraints (strength and stability inequalities) formulated based on the design code requirements [12] for all design sections of the structural members subjected to all design load combinations at the ultimate limit state as well as displacements constraints (stiffness inequalities) for the specified nodes of the bar system subjected to all design load combinations at the serviceability limit state should be included into the system of constraints Eqs. (1.2)-(1.3). Additional requirements, which describe structural, technological and serviceability particularities of the considered structure can be also included into the system Eqs. (1.2) - (1.3).

The design internal forces in the structural members used in the strength and stability inequalities of the system Eqs. (1.2) - (1.3) are considered as state variables depending on design variables $\vec{X}$ and can be calculated from the following linear equations system of the finite element method [13]:

$$
\mathbf{K}\left(\vec{X}_{G}, \vec{X}_{C S}\right) \times \vec{z}_{U L S, k}=\vec{p}_{U L S, k}\left(\vec{X}_{G}\right), k=\overline{1, N_{L C}^{U L S}} ;
$$

where $\mathbf{K}\left(\vec{X}_{G}, \vec{X}_{C S}\right)$ is the stiffness matrix of the finite element model of the bar system, which should be formed depending on the unknown (variable) 
cross-sectional dimensions of the structural members $\vec{X}_{C S}$, as well as unknown (variable) node coordinates of the structure $\vec{X}_{G} ; \vec{p}_{U L S, k}\left(\vec{X}_{G}\right)$ is the column-vector of the node's loads for $k^{\text {th }}$ design load combination of the ultimate limit state, which should be formed depending on unknown (variable) node coordinates of the structure $\vec{X}_{G} ; \vec{z}_{U L S, k}$ is the result column-vector of the node displacements for $k^{\text {th }}$ design load combination of the ultimate limit state, $\vec{z}_{U L S, k}=\mathbf{Z}_{\mathbf{F E M}, k}^{U L S}\left(\vec{X}_{G}, \vec{X}_{C S}\right)=\mathbf{Z}_{\mathbf{F E M}, k}^{U L S}(\vec{X}) ; N_{L C}^{U L S}$ is the number of the design ultimate load combinations. For each $i^{\text {th }}$ design section of $j^{\text {th }}$ structural member subjected to $k^{\text {th }}$ ultimate design load combination the design internal forces (axial force, bending moments and shear forces) can be calculated depending on node displacement column-vector $\vec{z}_{U L S, k}$.

The node displacement of the bar system used in stiffness inequalities of the system Eqs. (1.2) - (1.3) are also considered as state variables depending on design variables $\vec{X}$ and can be calculated from the following linear equations system of the finite element method [13]:

$$
\mathbf{K}\left(\vec{X}_{G}, \vec{X}_{C S}\right) \times \vec{z}_{S L S, k}=\vec{p}_{S L S, k}\left(\vec{X}_{G}\right), k=\overline{1, N_{L C}^{S L S}} ;
$$

where $\vec{p}_{S L S, k}\left(\vec{X}_{G}\right)$ is the column-vector of the node's loads for $k^{\text {th }}$ design load combination of the serviceability limit state, which should be formed depending on unknown (variable) node coordinates of the structure $\vec{X}_{G} ; \vec{z}_{U L S, k}$ is the result column-vector of the node displacements for $k^{\text {th }}$ design load combination of the serviceability limit state, $\vec{z}_{S L S, k}=\mathbf{Z}_{\mathbf{F E M}, k}^{S L S}\left(\vec{X}_{G}, \vec{X}_{C S}\right)=\mathbf{Z}_{\mathbf{F E M}, k}^{S L S}(\vec{X}) ; N_{L C}^{S L S}$ is the number of the design serviceability load combinations. For each $m^{\text {th }}$ node of the finite element model subjected to $k^{\text {th }}$ serviceability design load combination the design vertical and horizontal displacements can be calculated depending on node displacement column-vector $\vec{z}_{S L S, k}$.

2. An improved gradient projection method for solving the formulated parametric optimization problem. The parametric optimization problem stated as non-linear programming task by Eqs. (1.1) - (1.3) can be solved using a gradient projection method. The method of objective function gradient projection onto the active constraints surface with simultaneous correction of the constraints violations ensures effective searching for solution of the non-linear programming tasks occurred when optimum designing of the building structures $[14,15]$.

The gradient projection method operates with the first derivatives or gradients only of both the objective function Eq. (1.1) and constraints Eqs. (1.2) - (1.3). The method is based on the iterative construction of such sequence Eq. (2.1) of the approximations of the design variables $\vec{X}=\left\{X_{l}\right\}^{T}$, 
$\imath=\overline{1, N_{X}}$, that provides the convergence to the optimum solution (optimum values of the structural parameters):

$$
\vec{X}_{t+1}=\vec{X}_{t}+\Delta \vec{X}_{t},
$$

where $\vec{X}_{t}=\left\{X_{t}\right\}^{T}, \imath=\overline{1, N_{X}}$ is the current approximation to the optimum solution $\vec{X}^{*}$ that satisfies both constraints-equalities Eq. (1.2) and constraintsinequalities Eq. (1.3) with the extreme value of the objective function Eq. (1.1); $\Delta \vec{X}_{t}=\left\{\Delta X_{t}\right\}^{T}, \imath=\overline{1, N_{X}}$, is the increment vector for the current values of the design variables $\vec{X}_{t} ; t$ is the iteration's index. The start point of the iterative searching process $\vec{X}_{t=0}$ can be assigned as engineering estimation of the admissible design of the structure.

The active constraints only of constraints system Eqs. (1.2) - (1.3) should be considered at each iteration. A set of active constraints numbers A calculated for the current approximation $\vec{X}_{t}$ to the optimum solution (current design of the structure) is determined as:

$$
\mathbf{A}=\boldsymbol{\kappa} \cup \boldsymbol{\eta}, \boldsymbol{\kappa}=\left\{\kappa|| \psi_{\kappa}\left(\vec{X}_{t}\right) \mid \geq-\varepsilon\right\}, \boldsymbol{\eta}=\left\{N_{E C}+\eta \mid \phi_{\eta}\left(\vec{X}_{t}\right) \geq-\varepsilon\right\},
$$

where $\varepsilon$ is a small positive number introduced here in order to diminish the oscillations on movement alongside of the active constraints surface.

The increment vector $\Delta \vec{X}_{t}$ for the current values of the design variables $\vec{X}_{t}$ can be determined by the following equation:

$$
\Delta \vec{X}_{t}=\Delta \vec{X}_{\perp}^{t}+\Delta \vec{X}_{\square}^{t},
$$

where $\Delta \vec{X}_{\perp}^{t}$ is the vector calculated subject to the condition of elimination the constraint's violations; $\Delta \vec{X}_{\square}^{t}$ is the vector determined taking into consideration the improvement of the objective function value. Vectors $\Delta \vec{X}_{\square}^{t}$ and $\Delta \vec{X}_{\perp}^{t}$ are directed parallel and perpendicularly accordingly to the subspace with the vectors basis of the linear-independent constraint's gradients, such that:

$$
\left(\Delta \vec{X}_{\perp}^{t}\right)^{T} \Delta \vec{X}_{\square}^{t}=0 .
$$

The values of the constraint's violations for the current approximation $\vec{X}_{t}$ of the design variables are accumulated into the following vector:

$$
\mathbf{V}=\left(\psi_{\kappa}(\vec{X}) \forall \kappa \in \mathbf{\kappa} ; \phi_{\eta}(\vec{X}) \forall \eta \in \boldsymbol{\eta}\right) \text {. }
$$

Let us introduce a set $\mathbf{L}, \mathbf{L} \subseteq \mathbf{A}$, of the constraint's numbers, such that the gradients of the constraints at the current approximation $\vec{X}_{t}$ to the optimum solution are linear-independent.

Component $\Delta \vec{X}_{\perp}^{t}$ is calculated from the equation presented below: 


$$
\Delta \vec{X}_{\perp}^{t}=[\nabla \varphi] \vec{\mu}_{\perp},
$$

where $[\nabla \varphi]$ is the matrix that consists of components $\frac{\partial \psi_{\kappa}}{\partial X_{t}}$ and $\frac{\partial \phi_{\eta}}{\partial X_{t}}$, here $\imath=\overline{1, N_{X}}, \kappa \in \mathbf{L}, \eta \in \mathbf{L} ; \vec{\mu}_{\perp}$ is the column-vector that defines the design variables increment subject to the condition of elimination the constraint's violations. Vector $\vec{\mu}_{\perp}$ can be calculated as presented below.

In order to correct constraint's violations $\mathbf{V}$, vector $\Delta \vec{X}_{\perp}^{t}$ to a first approximation should also satisfy Taylor's theorem for the continuously differentiable multivariable function in the vicinity of point $\vec{X}_{t}$ for each constraint from set $\mathbf{L}$, namely:

$$
-\mathbf{V}=[\nabla \varphi]^{T} \Delta \vec{X}_{\perp}^{t} .
$$

With substitution of Eq. (2.5) into Eq. (2.6) we obtain the system of equations to determine column-vector $\vec{\mu}_{\perp}$ :

$$
[\nabla \varphi]^{T}[\nabla \varphi] \vec{\mu}_{\perp}=-\mathbf{V} .
$$

Component $\Delta \vec{X}_{\square}^{t}$ is determined using the following equation:

$$
\Delta \vec{X}_{\square}^{t}=\xi \times \vec{p}_{\nabla f}=\xi\left(\nabla \vec{f}-[\nabla \varphi] \vec{\mu}_{\square}\right),
$$

where $\nabla \vec{f}$ is the vector of the objective function gradient in the current point (current approximation of the design variables) $\vec{X}_{t}$; $\vec{p}_{\nabla f}$ is the projection of the objective function gradient vector onto the active constraints surface in the current point $\vec{X}_{t} ; \vec{\mu}_{\square}$ is the column-vector that defines the design variable's increment subject to the improvement of the objective function value. Columnvector $\vec{\mu}_{\square}$ can be calculated approximately using the least-square method by the following equation:

$$
[\nabla \varphi] \vec{\mu}_{\square} \approx \nabla \vec{f},
$$

or from the equation presented below:

$$
[\nabla \varphi]^{T}[\nabla \varphi] \vec{\mu}_{\square}=[\nabla \varphi]^{T} \nabla \vec{f} ;
$$

where $\xi$ is the step parameter, which can be calculated subject to the desired increment $\Delta f$ of the purpose function on movement along the direction of the purpose function anti-gradient. The increment $\Delta f$ can be assign as $5 \ldots 25 \%$ from the current value of the objective function $f\left(\vec{X}_{t}\right)$ :

$$
\Delta f=\xi(\nabla \vec{f})^{T} \nabla \vec{f}, \xi=\frac{\Delta f}{(\nabla \vec{f})^{T} \nabla \vec{f}},
$$


where in case of minimization Eq. (1.1) $\Delta f$ and $\xi$ accordingly have negative values. The parameter $\xi$ can be also calculated using the dependency presented below:

$$
\xi=\frac{\Delta f}{\left(\vec{p}_{\nabla f}\right)^{T} \nabla \vec{f}},
$$

that follows from the condition of attainment the desired increment of the objective function $\Delta f$ on the movement along the direction of the objective function anti-gradient projection onto the active constraints surface. Step parameter $\xi$ can be also selected as a result of numerical experiments performed for each type of the structure individually $[16,17]$.

Using Eqs. (2.5) and (2.8), Eq. (2.3) can be rewritten as presented below:

$$
\Delta \vec{X}_{t}=[\nabla \varphi] \vec{\mu}_{\perp}+\xi\left(\nabla \vec{f}-[\nabla \varphi] \vec{\mu}_{\square}\right),
$$

or

$$
\Delta \vec{X}_{t}=\xi \nabla \vec{f}+[\nabla \varphi]\left(\vec{\mu}_{\perp}-\xi \vec{\mu}_{\square}\right),
$$

where column-vectors $\vec{\mu}_{\perp}$ and $\vec{\mu}_{\square}$ are calculated using Eq. (2.7) and Eq. (2.9) or Eq. (2.10), respectively.

The linear-independent constraints of the system Eqs. (1.2) - (1.3) should be detected when constructing the matrix of the active constraints gradients $[\nabla \varphi]$ used by Eq. (2.7) and Eq. (2.9) or Eq. (2.10). Selection of the linearindependent constraints can be performed based on the equivalent transformations of the resolving equations of the gradient projection method using the non-degenerate transformation matrix $\mathbf{H}$, such that the sub-diagonal elements of the matrix $\mathbf{H}[\nabla \varphi]$ equal to zero. An orthogonal matrix of the elementary mapping (Householder's transformation) [18] has been used to select linear-independent constraints of the system Eqs. (1.2) - (1.3) as well as to form triangular structure of the nonzero elements of matrix $\mathbf{H}[\nabla \varphi][14]$.

Using Householder's transformations described above triangular structure of the nonzero elements of matrix $\mathbf{H}[\nabla \varphi]$ is formed step-by-step. Besides, Eq. (2.7) and Eq. (2.9) can be rewritten as follow:

$$
\begin{gathered}
\left([\nabla \varphi]^{T} \mathbf{H}^{T}\right)(\mathbf{H}[\nabla \varphi]) \vec{\mu}_{\perp}=-\mathbf{V} ; \\
\mathbf{H}[\nabla \varphi] \vec{\mu}_{\square} \approx \mathbf{H} \nabla \vec{f} .
\end{gathered}
$$

Equivalent Householder transformations of the resolving equations Eqs. (2.15), (2.16) have been proposed by the paper [14]. They increase numerical efficiency of the algorithm developed based on the considered method.

In order to calculate column-vectors $\vec{\mu}_{\perp}$ and $\vec{\mu}_{\square}$, it is required only to perform forward and backward substitutions in Eq. (2.15) and Eq. (2.16).

To accelerate the convergence of the minimization algorithm presented above, 
$h^{\text {th }}$ columns should be excluded from matrix $\mathbf{H}[\nabla \varphi]$. These columns correspond to those constraints from Eq. (1.3), for which the following inequality satisfies:

$$
\mu_{\perp h}-\xi \times \mu_{\llcorner h}>0 .
$$

As presented by the papers $[14,15]$, when $\mu_{\perp h}-\xi \times \mu_{\llcorner h}>0$, then the return onto the active constraints surface from the feasible region $\mathfrak{I}$ is performed with simultaneous degradation of the objective function value. At the same time, in case of $\mu_{\perp h}-\xi \times \mu_{\llcorner h}<0$, both the improvement of the objective function value and the return from the inadmissible region onto the active constraints surface are performed.

When excluding $h^{\text {th }}$ columns from matrix $\mathbf{H}[\nabla \varphi]$ corresponded to those constraints for which Eq. (2.17) is satisfied, the matrix $(\mathbf{H}[\nabla \varphi])_{\text {red }}$ with a broken (non-triangular) structure of the non-zero elements is obtained. The set $\mathbf{L}$ of the linear-independent active constraints numbers transforms into the set $\mathbf{L}_{\text {red }}$ respectively. At the same time, the vector of the constraint's violations $\mathbf{V}$ reduced into the vector $\mathbf{V}_{\text {red }}$ accordingly. In order to restore the triangular structure of the matrix $(\mathbf{H}[\nabla \varphi])_{\text {red }}$ with zero sub-diagonal elements, Givens transformations (Givens rotations) [18] can be used.

Considering Givens transformations, Eq. (2.15) and Eq. (2.16) for columnvectors $\left(\vec{\mu}_{\perp}\right)_{\text {red }}$ and $\left(\vec{\mu}_{\square}\right)_{\text {red }}$ can be rewritten as:

$$
\begin{gathered}
\left([\nabla \varphi]^{T} \mathbf{H}^{T}\right)_{\text {red }} \mathbf{G}^{T} \mathbf{G}(\mathbf{H}[\nabla \varphi])_{\text {red }}\left(\vec{\mu}_{\perp}\right)_{\text {red }}=-\mathbf{V}_{\text {red }} ; \\
\mathbf{G}(\mathbf{H}[\nabla \varphi])_{\text {red }}\left(\vec{\mu}_{\llcorner}\right)_{\text {red }} \approx \mathbf{G H} \nabla \vec{f} ;
\end{gathered}
$$

Equivalent transformations of the resolving equations Eqs. (2.18), (2.19) using Givens rotations (transformations with matrix $\mathbf{G}$ ) ensure acceleration of the iterative searching process Eq. (2.1) in those cases when Eq. (2.17) takes into account due to decreasing the amount of calculations [14].

The main resolving equation of the gradient method Eq. (2.13) and Eq. (2.14) can be rewritten as presented below:

$$
\Delta \vec{X}_{t}=(\mathbf{H}[\nabla \varphi])_{\text {red }}\left(\vec{\mu}_{\perp}\right)_{\text {red }}+\xi\left(\nabla \vec{f}-(\mathbf{H}[\nabla \varphi])_{\text {red }}\left(\vec{\mu}_{\square}\right)_{\text {red }}\right),
$$

or

$$
\Delta \vec{X}_{t}=\xi \nabla \vec{f}+(\mathbf{H}[\nabla \varphi])_{\text {red }}\left(\left(\vec{\mu}_{\perp}\right)_{\text {red }}-\xi\left(\vec{\mu}_{\square}\right)_{\text {red }}\right) .
$$

It should be noted that the lengths of the gradient vectors for the objective function Eq. (1.1), as well as for constraints Eqs. (1.2) - (1.3), remain as they were in scope of the proposed equivalent transformations ensuring the dependability of the optimization algorithm [14].

The determination the convergence criterion is the final question when using the iterative searching for the optimum point Eq. (2.1) described above. Considering the geometrical content of the gradient steepest descent method, 
we can assume that at the permissible point $\vec{X}_{t}$ the component of the increment vector $\Delta \vec{X}_{\square}^{t}$ for the design variables should be vanish, $\Delta \vec{X}_{\square}^{t} \rightarrow 0$, in case of approximation to the optimum solution of the non-linear programming task presented by Eqs. (1.1) - (1.5). So, the following convergence criterion of the iterative procedure Eq. (2.1) can be assigned:

$$
\left\|\Delta \vec{X}_{\square}^{k}\right\|=\sqrt{\sum_{l=1}^{N_{X}}\left(\Delta X_{\square, l}^{k}\right)^{2}}<\varepsilon_{1},
$$

where $\varepsilon_{1}$ is a small positive number. In the paper [14] the convergence criteria for the iterative procedure Eq. (2.1) has been presented in detail.

3. Mathematical model for parametric optimization of the lattice portal frame. A parametric optimization task for lattice portal frame of the steel warehouse framework designed as repository for the granulated sulfur has been considered. Building object locates in seaport Ust-Luga of Russian Federation The general building sizes are length $247.25 \mathrm{~m}$ and width $69.0 \mathrm{~m}$. Steel framework of the building consists of portal frames with span $69.0 \mathrm{~m}$ positioned along building length with bay $7.5 \mathrm{~m}$.

Steel portal frames consist of the lattice structural members fabricated from pipes with steel grade St20 according to design code [12]. Joints in the lattice structural members were designed using welded connections without gussets.

There is a service platform at the level $+28.25 \mathrm{~m}$ provided for supporting the crane-loader and conveyor (see Fig. 3.1). The load-bearing structures of the platform are suspended to the structural members of the portal frames. Welded I-beams of this platform were manufactured from the universal steel sheets of grade S245.

Design scheme of the steel lattice portal frame was assumed as a hingedbar structure with hinged column bases. Geometrical scheme of the portal frame was described using the set of nodes and bars with orientation on implementation of the finite element method for linear static analysis. Node coordinates of the design scheme were determined in Cartesian coordinate system and presented as expressions in dependence of geometrical design variables of the optimization task.

Dead loads included self weight of the portal frame, roof purlins, roof bracings, fire escape staircase and mezzanines, profiled panels which is used as non-warmth-keeping walling as well as service loads on fire escape staircase and mezzanines. Safety factors for the design loads and effects as well as safety factor for the building responsibility were defined according to [12]. Live loads (or technological loads) were accepted according to the target specification. Calculation the design values for climate loadings has been performed according to the requirements [12]. So, tree types of snow loads and two types of wind load have been considered when optimum designing of the steel portal frames.

Design loads and effects have been combined in 16 design load case combinations taken into account the combination factors according to requirements of design code [12]. All loads and effects on the structure were 
presented as concentrated loads at the nodes and were determined analytically depending on the variable parameters of the geometrical scheme.

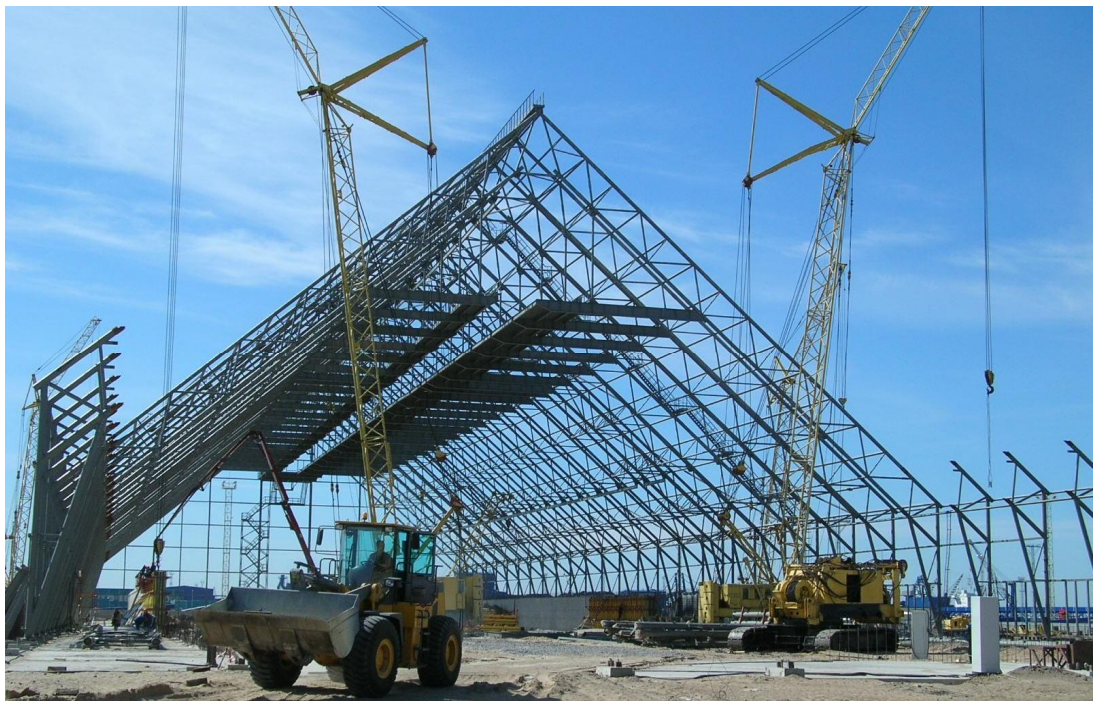

Fig. 3.1. Assembling process on job site (Photo has been provided by V. Shymanovsky Ukrainian Research and Design Institute of Steel Construction)

Mathematical model of the parametric optimization task for the steel portal frame with lattice structural members has been formulated as nonlinear programming task including the set of design variables, system of constraints as well as specified purpose function.

3.1. Design variables. Parameters of the geometric scheme of the portal frames have been considered as design variables. Variable parameters of the geometrical scheme were building height at the eave node $H_{z d k}$ and at the ridge $H_{z d}$, distance between upper and lower chords of the lattice rafter at the eave node hop and at the erection joints $h_{2}, h_{4}, h_{6} \mathrm{i} h_{7}$, distance between chords of the lattice column at the eave node bop and parameter $b_{7}$ (see Fig. 3.2). Start values for the design variables were accepted according to the design decision of the steel framework developed by Open Join-Stock Company "V. Shymanovsky Ukrainian Research and Design Institute of Steel Construction", namely: $\quad H_{z d}=39.58 \mathrm{~m}, \quad H_{z d k}=10.63 \mathrm{~m}$, $h_{2}=h_{4}=h_{6}=h_{7}=h_{o p}=b_{o p}=2.6 \mathrm{~m}, b_{7}=0.56 \mathrm{~m}$. Additionally, cross-sectional sizes of the structural members with circle hollow sections (CHS) for each stiffness type were considered as design variables (see Table 3.1). 
Table 3.1

Variable cross-sectional sizes for the CHS structural members of the portal frame

\begin{tabular}{|c|c|c|c|c|c|c|}
\hline $\begin{array}{l}\text { Destination and } \\
\text { location of } \\
\text { structural member }\end{array}$ & $\begin{array}{l}\text { Stiff- } \\
\text { ness } \\
\text { type } \\
\text { num- } \\
\text { ber }\end{array}$ & $\begin{array}{c}\text { Design } \\
\text { variables } \\
\text { name, } \\
\text { diameter } \times \\
\text { thickness }\end{array}$ & $\begin{array}{c}\text { Start } \\
\text { values, } \\
\mathrm{mm} \times \mathrm{mm}\end{array}$ & $\begin{array}{l}\text { Stiff- } \\
\text { ness } \\
\text { type } \\
\text { num- } \\
\text { ber }\end{array}$ & $\begin{array}{c}\text { Design } \\
\text { variables } \\
\text { name, } \\
\text { diameter } \times \\
\text { thickness }\end{array}$ & $\begin{array}{c}\text { Start } \\
\text { values, } \\
\mathrm{mm} \times \mathrm{mm}\end{array}$ \\
\hline \multirow{6}{*}{$\begin{array}{l}\text { Chords of the } \\
\text { lattice } \\
\text { structural } \\
\text { members }\end{array}$} & 1 & $d_{1} \times t_{1}$ & $299 \times 25$ & 7 & $d_{6} \times t_{7}$ & $299 \times 16$ \\
\hline & 2 & $d_{1} \times t_{2}$ & $299 \times 14$ & 8 & $d_{8} \times t_{8}$ & $299 \times 10$ \\
\hline & 3 & $d_{1} \times t_{3}$ & $299 \times 10$ & 9 & $d_{9} \times t_{9}$ & $299 \times 10$ \\
\hline & 4 & $d_{1} \times t_{4}$ & $299 \times 14$ & 10 & $d_{10} \times t_{10}$ & $299 \times 14$ \\
\hline & 5 & $d_{1} \times t_{5}$ & $299 \times 14$ & 11 & $d_{11} \times t_{11}$ & $180 \times 12$ \\
\hline & 6 & $d_{6} \times t_{6}$ & $299 \times 10$ & - & - & - \\
\hline \multirow{2}{*}{$\begin{array}{l}\text { Elements of the } \\
\text { lattice rafters }\end{array}$} & 12 & $d_{12} \times t_{12}$ & $152 \times 8$ & 14 & $d_{14} \times t_{14}$ & $102 \times 5$ \\
\hline & 13 & $d_{13} \times t_{13}$ & $121 \times 8$ & - & - & - \\
\hline \multirow{2}{*}{ Frame ridge } & 15 & $d_{15} \times t_{15}$ & $152 \times 8$ & 17 & $d_{17} \times t_{17}$ & $180 \times 12$ \\
\hline & 16 & $d_{16} \times t_{16}$ & $102 \times 5$ & 18 & $d_{18} \times t_{18}$ & $180 \times 12$ \\
\hline \multirow{2}{*}{$\begin{array}{l}\text { Elements of the } \\
\text { lattice columns }\end{array}$} & 19 & $d_{19} \times t_{19}$ & $299 \times 10$ & 21 & $d_{21} \times t_{21}$ & $299 \times 25$ \\
\hline & 20 & $d_{19} \times t_{20}$ & $299 \times 25$ & 22 & $d_{22} \times t_{22}$ & $102 \times 5$ \\
\hline $\begin{array}{l}\text { Suspension arm } \\
\text { of the service } \\
\text { platform }\end{array}$ & 23 & $d_{23} \times t_{23}$ & $180 \times 12$ & - & - & - \\
\hline
\end{tabular}

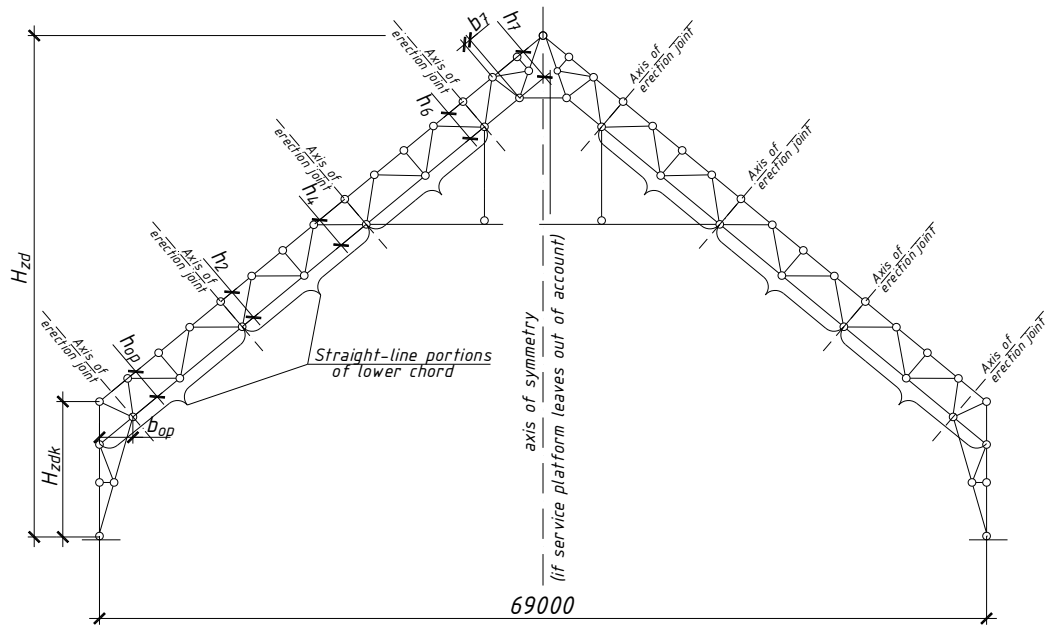

Fig. 3.2. The design scheme of the portal frame with specification of the variable geometrical parameters 
3.2. System of constraints. The system of constraints Eqs.(1.2)-(1.3) should cover strength and stability constraints formulated for all design sections of all structural members of the considered steel structure subjected to all design load combinations at the ultimate limit state. The following strength constraints have been included in the system of constraints Eqs. (1.2) - (1.3), formulated for all design sections, $\forall i=\overline{1, N}_{D S}$ ( $N_{D S}$ is the total number of the design sections in structural members), of all structural members, $\forall j=\overline{1, N_{B}}$ ( $N_{B}$ is the total number of the structural members), subjected to all ultimate load case combination, $\forall k=\overline{1, N_{L C}^{U L S}}$, namely normal stresses verifications:

$$
\frac{N_{i j k}(\vec{X})}{A_{n, j}\left(\vec{X}_{C S}\right) R_{y, j} \gamma_{c}}-1 \leq 0,
$$

where $\sigma_{i j k}(\vec{X})=\frac{N_{i j k}(\vec{X})}{A_{n, j}\left(\vec{X}_{C S}\right)}$ is the value of the normal stresses caused by axial force $N_{i j k}(\vec{X})$ acting in $i^{\text {th }}$ design section of $j^{\text {th }}$ structural member subjected to $k^{\text {th }}$ ultimate load case combination calculated from the linear equations system of the finite element method presented by Eq.(1.5); $A_{n, j}\left(\vec{X}_{C S}\right)$ is the net crosssectional area of $j^{\text {th }}$ structural member calculated depending on the variable cross-sectional dimensions of the structural members $\vec{X}_{C S} ; \gamma_{c}$ is the safety factor [12]; $R_{y . j}$ is the design strength for steel member subjected to tension, bending and compression; $R_{y} \gamma_{c}$ are allowable value for normal stresses [12]; $\sigma_{x, i j k}(\vec{X})$ are normal stresses at the specified cross-section point caused by internal forces acting in $i^{\text {th }}$ design section of $j^{\text {th }}$ structural member subjected to $k^{\text {th }}$ ultimate load case combination calculated from the linear equations system of the finite element method presented by Eq. (1.5). The value of the normal stresses $\sigma_{x, i j k}(\vec{X})$ at the specified cross-section point has been calculated depending on the variable geometrical parameters of the structure $\vec{X}_{G}$ and variable cross-sectional dimensions of the structural members $\vec{X}_{C S}$.

The following constraints on slenderness of the structural members have been included in the system of constraints Eqs. (1.2) $-(1.3), \forall j=\overline{1, N_{B}}$ :

$$
\frac{l_{e f, y, j}\left(\vec{X}_{G}\right)}{i_{y, j}\left(\vec{X}_{C S}\right) \lambda_{u y, j}}-1 \leq 0
$$




$$
\frac{l_{e f, z, j}\left(\vec{X}_{G}\right)}{i_{z, j}\left(\vec{X}_{C S}\right) \lambda_{u z, j}}-1,0 \leq 0,
$$

where $i_{y, j}\left(\vec{X}_{C S}\right)$ and $i_{z, j}\left(\vec{X}_{C S}\right)$ are radiuses of inertia for $j^{\text {th }}$ structural member's design cross-section relative to the main axis of inertia and calculated depending on the variable cross-sectional dimensions of the structural members $\vec{X}_{C S} ; l_{e f, y, j}\left(\vec{X}_{G}\right)$ and $l_{e f, z, j}\left(\vec{X}_{G}\right)$ are design lengths for $j^{\text {th }}$ structural member in the main planes of inertia calculated depending on the variable geometrical parameters of the structure $\vec{X}_{G} ; \lambda_{u y, j}$ and $\lambda_{u z, j}$ are the ultimate slenderness for $j^{\text {th }}$ structural member. Design lengths of the structural members $l_{e f, y, j}\left(\vec{X}_{G}\right)$ and $l_{e f, z, j}\left(\vec{X}_{G}\right)$ were defined according to [12] as: for chords, support diagonals and support columns of the lattice structural members $l_{e f, y, j}\left(\vec{X}_{G}\right)=l_{j}\left(\vec{X}_{G}\right) ; l_{e f, z, j}\left(\vec{X}_{G}\right)=l_{1, j}$; for other elements of the lattice structural members $l_{e f, y, j}\left(\vec{X}_{G}\right)=0.85 l_{j}\left(\vec{X}_{G}\right) ; l_{e f, z, j}\left(\vec{X}_{G}\right)=0.85 l_{1, j}$; here $l_{j}$ is the geometrical length for $j^{\text {th }}$ bar of lattice structural member; $l_{1, j}$ is the distance between out-of-plane restraints of the member from the horizontal displacements in out-of-plane direction. Ultimate values for the slenderness of the lattice structural members were specified according to [12] as: $\lambda_{u y, j}=\lambda_{u z, j}=400$ for all tensioned members; $\lambda_{u y, j}=\lambda_{u z, j}=150$ for all compressed members.

The following stability constraints have been included in the system of constraints Eqs. (1.2) - (1.3), formulated for all design sections, $\forall i=\overline{1, N}_{D S}$, of the structural members subjected to all ultimate load case combination, $\forall k=\overline{1, N_{L C}^{U L S}}$, namely flexural buckling verifications for all structural members subjected to axial compression force $N_{i j k}(\vec{X}), \forall j=\overline{1, N_{B}}$ :

$$
\begin{gathered}
\frac{N_{i j k}(\vec{X})}{\varphi_{y, j}\left(\vec{X}_{G}, \vec{X}_{C S}\right) A_{j}\left(\vec{X}_{C S}\right) R_{y, j} \gamma_{c}}-1 \leq 0 ; \\
\frac{N_{i j k}(\vec{X})}{\varphi_{z, j}\left(\vec{X}_{G}, \vec{X}_{C S}\right) A_{j}\left(\vec{X}_{C S}\right) R_{y, j} \gamma_{c}}-1 \leq 0 ;
\end{gathered}
$$

where $A_{j}\left(\vec{X}_{C S}\right)$ is the gross cross-sectional area of $j^{\text {th }}$ structural member calculated depending on the variable cross-sectional dimensions of the structural members $\vec{X}_{C S} ; \varphi_{y, j}\left(\vec{X}_{G}, \vec{X}_{C S}\right)$ and $\varphi_{z, j}\left(\vec{X}_{G}, \vec{X}_{C S}\right)$ are column's stability factors corresponded to flexural buckling relative to the main axes of inertia and 
calculated depending on the design lengths $l_{e f, y, j}\left(\vec{X}_{G}\right), l_{e f, z, j}\left(\vec{X}_{G}\right)$, crosssection type and cross-section geometrical properties for the $j^{\text {th }}$ structural member [12]. The flexural buckling factors $\varphi_{y, j}\left(\vec{X}_{G}, \vec{X}_{C S}\right)$ and $\varphi_{z, j}\left(\vec{X}_{G}, \vec{X}_{C S}\right)$ calculated depending on the variable geometrical parameters of the structure $\vec{X}_{G}$ and variable cross-sectional dimensions of the structural members $\vec{X}_{C S}$.

The following local buckling constraints have been also included into the system of constraints:

$$
\begin{aligned}
& \frac{\bar{\lambda}_{w, j}\left(\vec{X}_{C S}\right)}{\bar{\lambda}_{u w, j}(\vec{X})}-1 \leq 0 ; \\
& \frac{\bar{\lambda}_{f, j}\left(\vec{X}_{C S}\right)}{\bar{\lambda}_{u f, j}(\vec{X})}-1 \leq 0,
\end{aligned}
$$

where $\bar{\lambda}_{w, j}\left(\vec{X}_{C S}\right)$ and $\bar{\lambda}_{f, j}\left(\vec{X}_{C S}\right)$ are the non-dimensional slenderness of the web and flange respectively of the cross-section for $j^{\text {th }}$ structural member; $\bar{\lambda}_{u w, j}(\vec{X})$ and $\bar{\lambda}_{u f, j}(\vec{X})$ are the maximum values for corresponded nondimensional slenderness for column structural members calculated depending on the internal forces (ration of the bending moment to the axial force), as well as depending on the design lengths $l_{e f, y, j}, l_{e f, z, j}$, cross-section type and crosssection geometrical properties for the $j^{\text {th }}$ structural member [12]. The nondimensional slenderness $\bar{\lambda}_{w, j}\left(\vec{X}_{C S}\right)$ and $\bar{\lambda}_{f, j}\left(\vec{X}_{C S}\right)$ calculated depending on the variable cross-sectional dimensions of the structural members $\vec{X}_{C S}$ only. At the same time, the maximum values for corresponded non-dimensional slenderness $\bar{\lambda}_{u w, j}(\vec{X})$ and $\bar{\lambda}_{u f, j}(\vec{X})$ calculated depending on the variable geometrical parameters of the structure $\vec{X}_{G}$ and variable cross-sectional dimensions of the structural members $\vec{X}_{C S}$.

The system of constraints Eqs. (1.2) - (1.3) has been also covered the displacements constraints (stiffness inequalities) for the specified nodes of the considered steel structure subjected to all design load combinations at the serviceability limit state. The following horizontal and vertical displacements constraints have been included into the system of constraints Eqs. (1.2) - (1.3), formulated for all nodes, $\forall m=\overline{1, N_{N}}$ ( $N_{N}$ is the total number of nodes in the considered steel structure), of the steel structure subjected to all serviceability load case combination, $\forall k=\overline{1, N_{L C}^{S L S}}$, namely: 


$$
\begin{aligned}
& \frac{\delta_{x, m k}(\vec{X})}{\delta_{u x, m}}-1 \leq 0 ; \\
& \frac{\delta_{z, m k}(\vec{X})}{\delta_{u z, m}}-1 \leq 0,
\end{aligned}
$$

where $\delta_{x, m k}(\vec{X})$ and $\delta_{z, m k}(\vec{X})$ are the horizontal and vertical displacements respectively for $l^{\text {th }}$ node of the steel structure subjected to $k^{\text {th }}$ serviceability load case combination calculated from the linear equations system of the finite element method presented by Eq. (1.6); $\delta_{u x, m}$ and $\delta_{u z, m}$ are the allowable horizontal and vertical displacements for $m^{\text {th }}$ structural node. Ultimate values for linear node displacements of the steel lattice portal frame were calculated according to [12] as $\delta_{u x, m}=H_{z d} / 210$ and $\delta_{u z, m}=L / 300=230 \mathrm{~mm}$.

Additional requirements that describe structural, technological and serviceability particularities of the considered structure, as well as constraints on the building functional volume (see Fig. 3.3) can be also included into the system Eqs. (1.2) - (1.3). In particular these requirements can be presented in the form of constraints on lower and upper values of the design variables, $\forall \boldsymbol{\imath}=\overline{1, N_{X}}$ :

$$
\begin{aligned}
& 1-\frac{X_{\iota}}{X_{\iota}^{L}} \leq 0 ; \\
& \frac{X_{\iota}}{X_{\iota}^{U}}-1 \leq 0,
\end{aligned}
$$

where $X_{l}^{L}$ and $X_{t}^{U}$ are the lower and upper bounds for the design variable $X_{l} ; N_{X}$ is the total number of the design variables.

Additional constraints on cross-sectional sizes of the structural members with circle hollow sections type have been formulated according to the requirements of [12]. There were constraints of permissible minimal thickness and permissible maximum diameter-to-thickness ratio for the structural members, namely, $\forall l=\overline{1, N_{S T}}$ :

$$
\begin{aligned}
& 1,0-\frac{t_{l}}{t_{\min , l}} \leq 0 ; \\
& \frac{D_{l}}{t_{l} \delta_{\max , l}}-1,0 \leq 0,
\end{aligned}
$$

where $l$ is the number of the stiffness type; $N_{S T}$ is the overall quantity of the stiffness types in the considered steel lattice portal frame; $t_{l}$ and $D_{l}$ are thickness and diameter of the circle hollow section for $l^{\text {th }}$ stiffness type (see Table 3.1) respectively; $t_{\min , l}$ is the minimum thickness of the circle hollow 
section in accordance with design code [12] as $t_{\text {min, } l}=3 \mathrm{~mm}$ for chords, support diagonals and support columns of lattice structural members and $t_{\min , l}=2.5 \mathrm{~mm}$ for other lattice elements; $\delta_{\max , l}$ is the maximum diameter-tothickness ratio for the structural member with circle hollow section in accordance with design code [12] depending on the yield stress value $R_{y n}=245 \mathrm{MPa}<295 \mathrm{MPa}$ as $\delta_{\text {max }, l}=30$ for chords elements of the lattice structural members and $\delta_{\max , l}=90$ for other lattice elements.

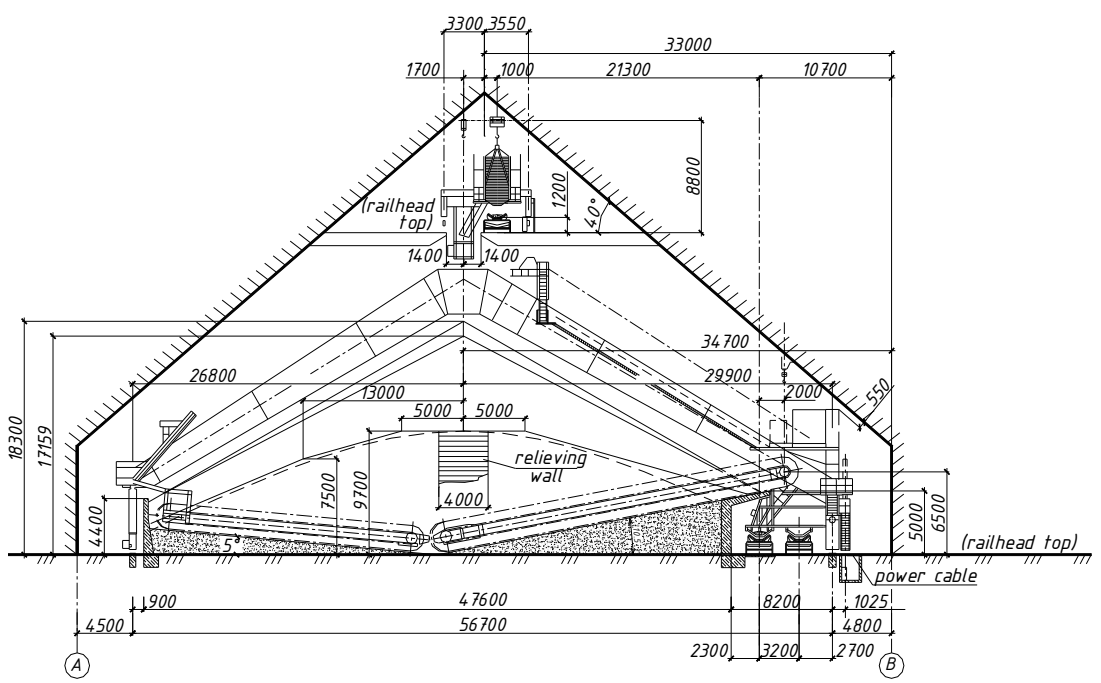

Fig. 3.3. Technological equipments and constraints that describe useful space in the building

The following constraints that describe conditions for designing gusset-less welded joints between CHS structural members formulated according to the requirements [12] have been also included in the system Eqs. (1.2) - (1.3), $q, p=1 \ldots N_{S T}:$

$$
0,3 d_{p} \leq d_{q} \leq d_{p},
$$

where $p$ and $q$ are the numbers of the stiffness types of structural members connected in the joint, here $p$ is the number of the chord's stiffness type; $q$ is the number of the lattice stiffness type.

3.3. Objective function. Minimum weight as well as minimum construction budget has been considered as purpose function. Analytical expression for the structural weight $\mathbf{M}\left(\vec{X}_{G}, \vec{X}_{C S}\right)$ depending on the variable cross-sectional sizes of the members can be written by the following formula:

$$
\mathbf{M}\left(\vec{X}_{G}, \vec{X}_{C S}\right)=\varphi \rho \sum_{j=1}^{N_{E}} A_{j} l_{j}=4 \pi \varphi \rho \sum_{j=1}^{N_{E}} t_{j}\left(D_{j}-t_{j}\right) l_{j} \rightarrow \min ,
$$


where $A_{j}$ and $l_{j}$ are gross cross-sectional area and geometrical length for $j^{\text {th }}$ structural member respectively; $\rho$ - steel density, $\rho=7850 \mathrm{~kg} / \mathrm{m}^{3} ; \varphi$ is the factor that takes into account the increment of structural weight due to the present of the adjunct elements in the structural members and joints (stiffeners, ribs, end-plates, gussets etc.), $\varphi$ was defined according to the steel specification mentioned in the source project for the warehouse framework, $\varphi \square 1,1$.

Construction budget of the steel portal frame with lattice structural members taken into account construction budget of mezzanines erected at the level $+28,25$ can be presented as follow:

$$
\mathbf{K}=C_{m n f}^{l t}+C_{m n f}^{s l}+C_{a s m}+C_{a s m}^{w l}+C_{c . p .}+C_{q . c .}+C_{m a t},
$$

where $C_{m n f}^{l t}$ is the manufacturing cost of lattice structural members; $C_{m n f}^{s l}$ is the manufacturing cost of mezzanine's structural members; $C_{a s m}$ is the assembly cost for steel portal frame; $C_{a s m}^{w l}$ is the assembly cost for walling; $C_{c . p .}$ is the cost on the work package for corrosion protection of the steel framework; $C_{q . c .}$ is the cost for the quality control of welded connections; $C_{\text {mat }}$ is the material cost for structural members of the steel portal frame. Analytical expression of the construction budget for manufacturing and erection of the steel lattice portal frame depending on the design variables have been presented by the following, UAH:

$$
\begin{aligned}
\mathbf{K}= & 20670 \mathbf{M}\left(\vec{X}_{G}, \vec{X}_{C S}\right)+1525 D_{o v}\left(\vec{X}_{G}\right)+1300 H_{z d k}+ \\
& +110 \mathbf{A}_{\mathbf{s}}\left(\vec{X}_{G}, \vec{X}_{C S}\right)+21120 \rightarrow \min ,
\end{aligned}
$$

where $D_{o v}$ is the half-rafter length, $D_{o v}=\left((0,5 L)^{2}+\left(H_{z d}-H_{z d k}\right)^{2}\right)^{\frac{1}{2}} ; L$ is the portal frame span, $L=69 \mathrm{~m} ; \mathbf{A}_{\mathbf{s}}\left(\vec{X}_{G}, \vec{X}_{C S}\right)$ is the total surface area of the steel lattice portal frame to be subjected to anti-corrosion treatment.

4. A parametric optimization algorithm based on the gradient projection method. Let present the following numerical algorithm to solve the parametric optimization problem for steel structures formulated above.

Step 1. Describing an initial design (a set of design variables) and initial data for structural optimization.

The design variable vector $\vec{X}_{k}=\left(\vec{X}_{G}, \vec{X}_{C S}\right)_{k}^{T}$ has been specified, where $k$ is the iteration index, $k=0$. The structural topology, cross-section types and node type connections of the bars, the support conditions of the bar system, as well as loading patterns, load case combinations and load design values are prescribed and constants.

Initial data for optimization of the considered steel structure are design strength for steel member $R_{y}$, safety factor $\gamma_{c}$, factors to define flexural design lengths $l_{e f, y, j}, l_{e f, z, j}$ for all column structural members; allowable 
values for horizontal and vertical displacements $\delta_{u x, l}$ and $\delta_{u z, l}$ of the specified nodes of the considered steel structure; lower $\vec{X}^{L}$ and upper $\vec{X}^{U}$ bounds for the design variables; as well as specified objective function $f\left(\vec{X}_{k}\right)$.

Step 2. Calculation of the geometrical and design lengths for all structural members.

The geometrical lengths $l_{j}$ of all structural members are calculated based on the node coordinates of the considered steel structure. The latter depend on the unknown (variable) geometrical parameters of the structure $\vec{X}_{G}$. The design lengths $l_{e f, y, j}, l_{e f, z, j}$ of all column structural members are calculated using calculated geometrical lengths $l_{j}$ and initial data relating to the design length factors. The latter are constant during the iteration process presented below. Variation of the geometrical lengths $l_{j}$ and corresponded design lengths $l_{e f, y, j}$, $l_{e f, z, j}$ on the further iterations has been performed based on the current values of the variable (unknown) parameters $\vec{X}_{G}$ of the geometrical scheme.

Step 3. Calculation of the cross-section dimensions and geometrical properties for all design cross-sections.

Geometrical properties of the design cross-sections (areas, moments of inertia, elastic section moments, radiuses of inertia, etc.), as well as nondimensional slenderness for cross-section elements (webs and flanges) $\bar{\lambda}_{w, j}\left(\vec{X}_{C S}\right)$ and $\bar{\lambda}_{f, j}\left(\vec{X}_{C S}\right)$ have been calculated depending on the current values of the unknown (variable) cross-section dimensions $\vec{X}_{C S}$.

Step 4. Linear structural analysis of the considered steel structure.

For each $m^{\text {th }}$ node of the finite element model subjected to $k^{\text {th }}$ serviceability load case combination the displacements and rotations, as well as the design horizontal $\delta_{x, m k}(\vec{X})$ and vertical $\delta_{z, l k}(\vec{X})$ displacements can be calculated using the linear equations system of the finite element method presented by Eq. (1.6).

For each $i^{\text {th }}$ design section of $j^{\text {th }}$ structural member subjected to $k^{\text {th }}$ ultimate load case combination the design internal forces can be calculated using the linear equations system of the finite element method presented by Eq. (1.5).

Step 5. Calculation of the state variables (stresses, buckling factors, allowable non-dimensional slenderness etc.).

The value of the normal $\sigma_{x, i j k}(\vec{X})$ stresses at the specified cross-section point has been calculated depending on the axial force acting in $i^{\text {th }}$ design section of $j^{\text {th }}$ structural member subjected to $k^{\text {th }}$ ultimate load case combination as presented by the design code.

The flexural buckling factors $\varphi_{y, j}\left(\vec{X}_{G}, \vec{X}_{C S}\right), \varphi_{z, j}\left(\vec{X}_{G}, \vec{X}_{C S}\right)$ have been calculated depending on the corresponded design lengths, cross-section type 
and cross-section geometrical properties for the structural members according to the design code [12].

The maximum values for corresponded non-dimensional slenderness $\bar{\lambda}_{u w, j}(\vec{X})$ and $\bar{\lambda}_{u f, j}(\vec{X})$ for column structural members have been calculated depending on the design lengths $l_{e f, y, j}, l_{e f, z, j}$, cross-section type and crosssection geometrical properties for the $j^{\text {th }}$ structural member [12].

Step 6. Verifications of the constraints and construction the set of active constraints numbers A .

Verification of the constraints Eqs. (3.1), (3.4), (3.5) has been performed for all ultimate load case combinations and all design cross-sections of all structural members. Verification of the constraints Eqs. (3.8), (3.9) have been also conducted for all serviceability load case combinations and all design structural nodes. Additional requirements in the form of constraints Eqs. (3.10), (3.11) on lower and upper values of the design variables, local buckling constraints Eqs. (3.6), (3.7), constraints on the member's slenderness Eqs. (3.2), (3.3), constraint Eq. (3.12) on permissible minimal thickness, constraint Eq. (3.13) on permissible maximum diameter-to-thickness ratio for the structural members, as well as the conditions Eq. (3.14) for designing gusset-less welded joints between structural members with circle hollow sections have been also verified. Set of the active constraints numbers A calculated for the current approximation $\vec{X}_{k}$ has been constructed according to Eq. (2.2).

Step 7. Calculation of the current objective function value $f\left(\vec{X}_{k}\right)$, objective function gradient $\nabla f\left(\vec{X}_{k}\right)$ and determination of the desired decrement of the objective function value $\Delta f\left(\vec{X}_{k}\right)$.

The objective function gradient $\nabla f\left(\vec{X}_{k}\right)$ can be calculated by the numerical differentiation with respect to the design variables using the finite difference approximation. The desired decrement of the objective function value $\Delta f\left(\vec{X}_{k}\right)$ can be assigned as $5 . . .25 \%$ from the current objective function value $f\left(\vec{X}_{k}\right)$.

Step 8. Construction of the constraint's violations vector $\mathbf{V}$ and the matrix of the active constraint's gradients $[\nabla \varphi]$. The vector of the values of the constraint's violations $\mathbf{V}$ and the matrix of the constraint's gradients $[\nabla \varphi]$ are constructed for active constraints only according to the set of active constraints numbers A .

Step 9. Construction the matrix of active linear-independent constraint's gradients with triangular structure. The set of linear-independent constraint's numbers $\mathbf{L}$ and the matrix of active linear-independent constraint's gradients $\mathbf{H}[\nabla \varphi]$ with triangular structure are constructed according to the algorithm presented by the paper [14]. 
Step 10. Step parameter $\xi$ calculation. Step parameter $\xi$ has been calculated according to Eq. (2.11) or Eq. (2.12) and can be modified on the further iterations depending on convergence of the iterative process presented by Eq. (2.1).

Step 11. Calculation the column-vectors $\vec{\mu}_{\perp}$ and $\vec{\mu}_{\neg}$ which define the design variables increment subject to the condition of elimination the constraint's violations and subject to the improvement of the objective function value. The vectors $\vec{\mu}_{\perp}$ and $\vec{\mu}_{1}$ can be calculated using Eq. (2.18) and Eq. (2.19) respectively.

If some $h^{\text {th }}$ component of the column-vectors $\vec{\mu}_{\perp}$ and $\vec{\mu}_{\square}$ satisfies Eq. (2.17), the corresponded constraint gradient $\nabla \varphi_{h}$ has been excluded from the matrix $[\nabla \varphi]$, and corresponded violations $V_{h}$ has been excluded from the vector $\mathbf{V}$, as well as the return to step 9 has to be conducted. In contrary case transition to the step 11 has been performed.

Step 12. Calculation the increment vector for the current design variables and determination the improved approximation to the optimum solution. The increment vector $\Delta \vec{X}_{k}$ for the current design variables values $\vec{X}_{k}$ has been calculated according to Eq. (2.20) or Eq. (2.21). The improved approximation $\vec{X}_{k+1}$ to the optimum solution has been determined according to Eq. (2.1).

Step 13. Stop criteria verification of iterative searching for the optimum solution. If all constraints Eqs. (3.1)-(3.14) are satisfied with appropriate accuracy, as well as inequality Eq. (2.22) or one of the stop criteria described by the paper [14] is also satisfied, then transition to the step 13 has been performed. In contrary case return to the step 1 has been conducted with $k \leftarrow k+1$.

Step 14. Discretization the optimum solution $\vec{X}_{k}$ obtained in the continuum space of the design variables.

Step 15. Optimum parameters of the structure is $\vec{X}_{k}$ with optimum value of the objective function $f\left(\vec{X}_{k}\right)$.

Figure 4.1 presents the flow chart for structural optimization according to the searching technique describing by the gradient projection method considered above. 


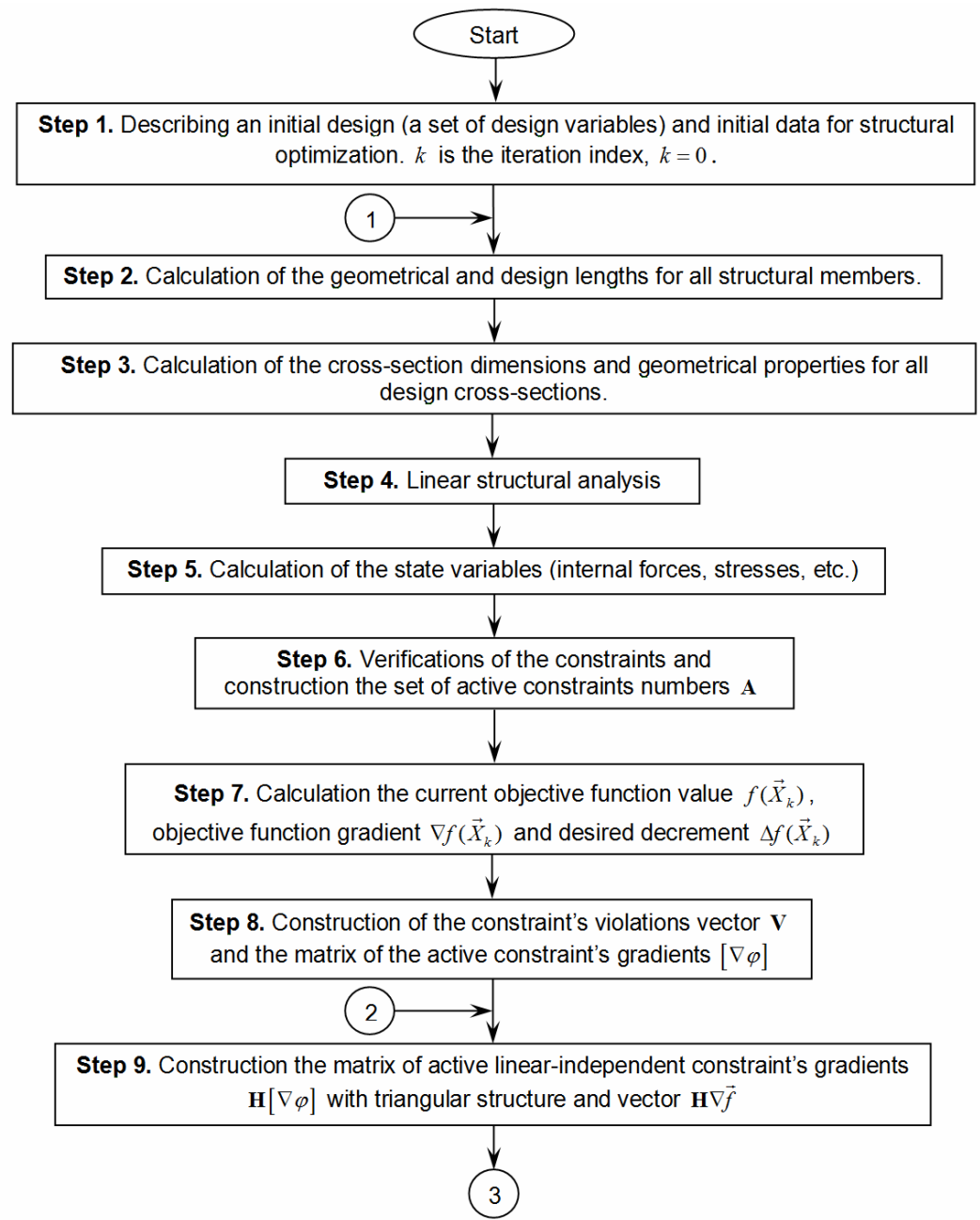

Fig. 4.1. The flow chart for structural optimization according to the searching technique based on the gradient projection method. 


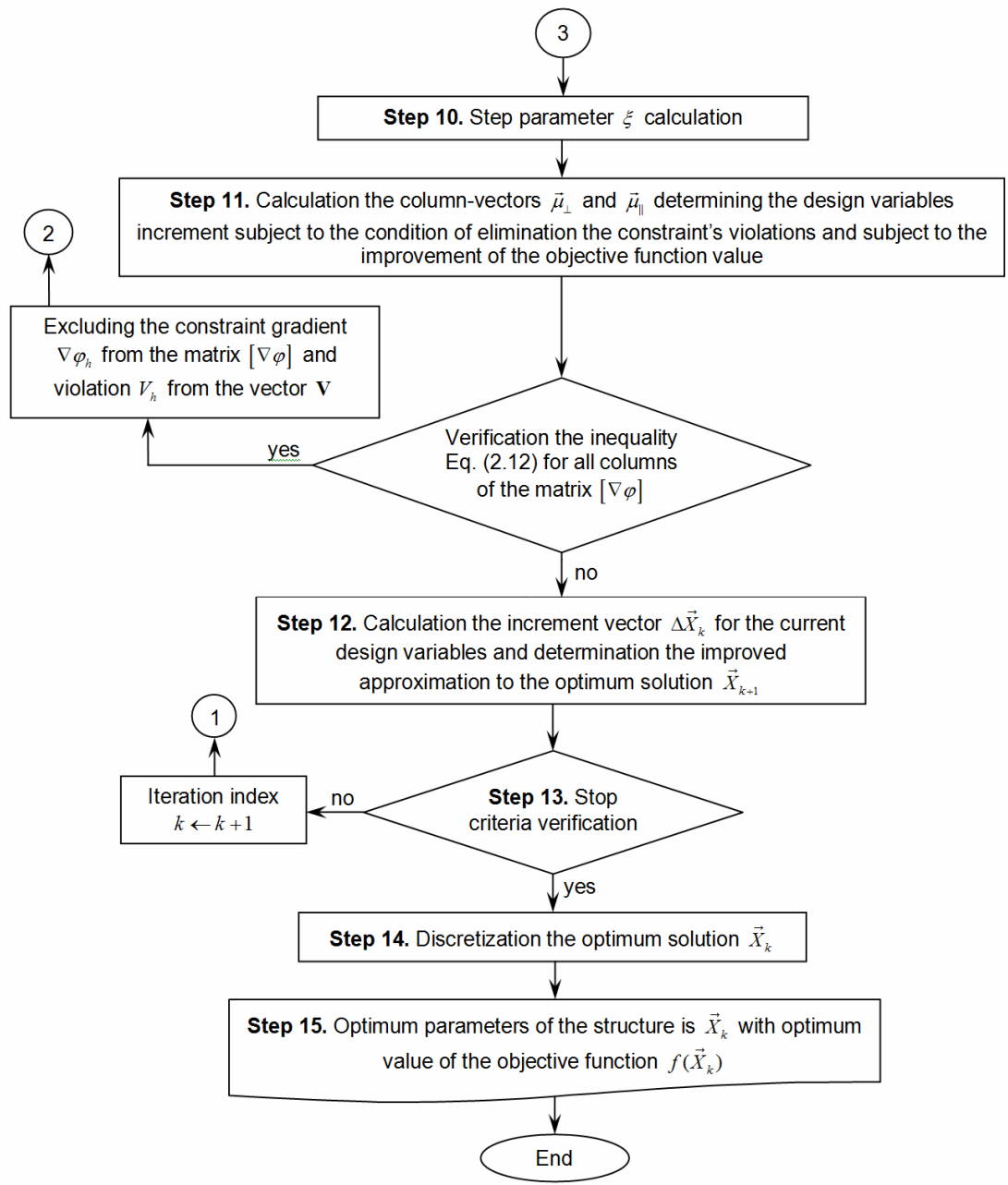

Fig. 4.1 (continuation). The flow chart for structural optimization according to the searching technique based on the gradient projection method

5. Results and discussion. A parametric optimization methodology presented above has been realized in software $\operatorname{OptCAD}[19,20]$. The software provides solutions to a wide range of problems, namely: (i) linear static analysis of bar structures; (ii) verification of the load-bearing capacity of the structural members according to specified design code; (iii) searching for values of the structural parameters when structure complies with design code requirements and designer's criterions; (iv) parametric optimization of the steel bar structures by the determined criterion. 


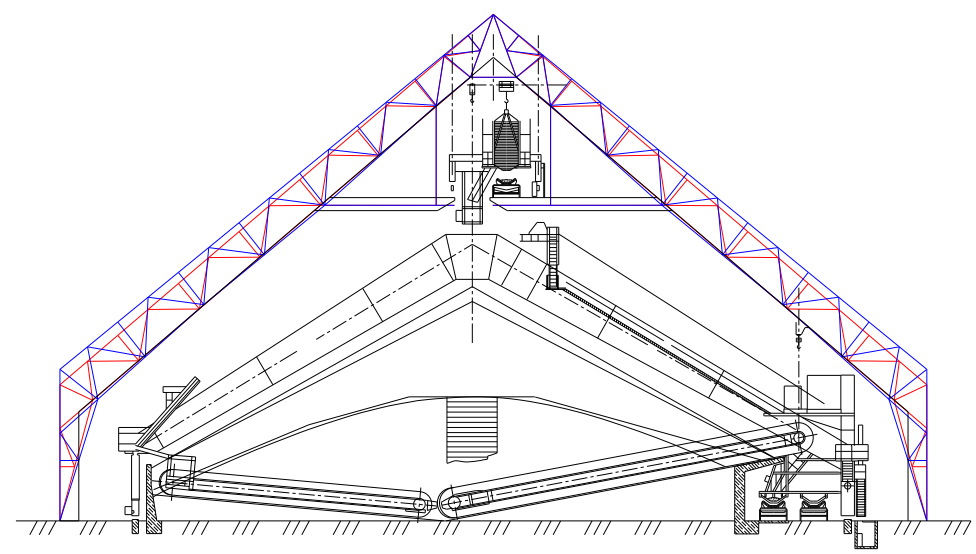

Fig. 5.1. The optimum design decision by the criterion of minimum structural weight when lower chord of the lattice rafter is straight-line.

Table 5.1

Optimal values for variable geometrical parameters of the portal frame's design scheme

\begin{tabular}{|c|c|c|c|c|c|}
\hline \multirow{2}{*}{ Design variable } & \multirow{2}{*}{$\begin{array}{c}\text { Start } \\
\text { value, } \mathrm{m}\end{array}$} & \multicolumn{3}{|c|}{ Optimum values, m, by the criterion of minimum } \\
\cline { 3 - 6 } & & \multicolumn{2}{|c|}{ weight } & \multicolumn{2}{c|}{$\begin{array}{c}\text { costs on fabrication and } \\
\text { erection }\end{array}$} \\
\cline { 3 - 6 } & & straight-line & polygonal & straight-line & polygonal \\
\hline$H_{z d}$ & 39.58 & 38.82 & 39.55 & 38.74 & 39.44 \\
\hline$H_{z d k}$ & 10.63 & 11.92 & 11.84 & 12.08 & 12.03 \\
\hline$h_{2}$ & 2.60 & - & 3.23 & - & 3.31 \\
\hline$h_{4}$ & 2.60 & - & 3.21 & - & 3.23 \\
\hline$h_{6}$ & 2.60 & - & 2.68 & - & 2.70 \\
\hline$h_{7}$ & 2.60 & 2.18 & 2.68 & 2.13 & 2.61 \\
\hline$b_{7}$ & 0.55773 & 1.00 & 0.56 & 1.05 & 0.63 \\
\hline$h_{o p}$ & 2.60 & 3.61 & 3.72 & 3.73 & 3.87 \\
\hline$b_{o p}$ & 2.60 & 3.08 & 3.02 & 3.02 & 2.95 \\
\hline Weight, $\times \mathbf{1 0}$, $\mathbf{k g}$ & $\mathbf{3 0 . 7 8}$ & $\mathbf{1 8 . 9 8}$ & $\mathbf{1 8 . 4 5}$ & & \\
\hline Costs, UAH & $\mathbf{7 8 6 6 8 1}$ & & & $\mathbf{5 3 4 6 4 7}$ & $\mathbf{5 2 4 2 5 7}$ \\
\hline
\end{tabular}


Table 5.2

Optimal values for variable cross-sectional sizes of the lattice structural members of the portal frame

\begin{tabular}{|c|c|c|c|c|c|c|c|}
\hline \multirow{6}{*}{$\begin{array}{l}\text { Design } \\
\text { variable }\end{array}$} & \multirow{6}{*}{$\begin{array}{c}\text { Start } \\
\text { value, } \\
\mathrm{m}\end{array}$} & \multicolumn{6}{|c|}{ Optimum values, $\mathrm{mm} \times \mathrm{mm}$, by the criterion of minimum } \\
\hline & & \multicolumn{3}{|c|}{ weight } & \multicolumn{3}{|c|}{$\begin{array}{c}\text { costs on fabrication and } \\
\text { erection }\end{array}$} \\
\hline & & \multicolumn{6}{|c|}{ when lower chord of the lattice rafter is } \\
\hline & & $\begin{array}{l}\text { straight- } \\
\text { line }\end{array}$ & \multicolumn{2}{|c|}{ polygonal } & $\begin{array}{l}\text { straight- } \\
\text { line }\end{array}$ & \multicolumn{2}{|c|}{ polygonal } \\
\hline & & \multicolumn{6}{|c|}{ in the search space } \\
\hline & & \multicolumn{2}{|c|}{ continuous } & discrete & \multicolumn{2}{|c|}{ continuous } & discrete \\
\hline$d_{1} \times t_{1}$ & $299 \times 25$ & $183.4 \times 8.4$ & $192.3 \times 8.6$ & $194 \times 9.0$ & $173.9 \times 9.3$ & $172.9 \times 8.6$ & $168 \times 11.0$ \\
\hline$d_{1} \times t_{2}$ & $299 \times 14$ & $183.4 \times 6.1$ & $192.3 \times 6.4$ & $194 \times 7.0$ & $173.9 \times 6.9$ & $172.9 \times 6.3$ & $168 \times 8.0$ \\
\hline$d_{1} \times t_{3}$ & $299 \times 10$ & $183.4 \times 6.9$ & $192.3 \times 6.5$ & $194 \times 6.5$ & $173.9 \times 7.3$ & $172.9 \times 7.4$ & $168 \times 8.5$ \\
\hline$d_{1} \times t_{4}$ & $299 \times 14$ & $183.4 \times 8.5$ & $192.3 \times 9.3$ & $194 \times 9.0$ & $173.9 \times 10.7$ & $172.9 \times 9.3$ & $168 \times 11.0$ \\
\hline$d_{1} \times t_{5}$ & $299 \times 14$ & $183.4 \times 6.1$ & $192.3 \times 6.4$ & $194 \times 6.5$ & $173.9 \times 5.8$ & $172.9 \times 5.8$ & $168 \times 6.0$ \\
\hline$d_{6} \times t_{6}$ & $299 \times 10$ & $297.4 \times 9.9$ & $303.1 \times 10.1$ & $299 \times 10.0$ & $298.1 \times 9.9$ & $292.3 \times 9.7$ & $299 \times 10.0$ \\
\hline$d_{6} \times t_{7}$ & $299 \times 16$ & $297.4 \times 11.3$ & $303.1 \times 11.4$ & $299 \times 12.0$ & $298.1 \times 11.6$ & $292.3 \times 11.5$ & $299 \times 12.0$ \\
\hline$d_{8} \times t_{8}$ & $299 \times 10$ & $264.4 \times 8.8$ & $269.4 \times 9.0$ & $299 \times 10.0$ & $269.0 \times 9.0$ & $263.6 \times 8.8$ & $273 \times 9.5$ \\
\hline$d_{9} \times t_{9}$ & $299 \times 10$ & $203.0 \times 6.8$ & $210.7 \times 7.0$ & $194 \times 8.5$ & $211.5 \times 7.0$ & $202.8 \times 6.8$ & $219 \times 7.5$ \\
\hline$d_{10} \times t_{10}$ & $299 \times 14$ & $143.5 \times 4.8$ & & & $148.1 \times 4.9$ & $143.3 \times 4.8$ & $146 \times 5.5$ \\
\hline$d_{11} \times t_{11}$ & $180 \times 12$ & $183.4 \times 9.7$ & & & $173.9 \times 11.5$ & $172.9 \times 11.1$ & $168 \times 13.0$ \\
\hline$d_{12} \times t_{12}$ & $152 \times 8$ & $161.2 \times 4.5$ & $165.6 \times 4.6$ & $152 \times 5.5$ & $164.9 \times 4.6$ & $160.8 \times 4.5$ & $168 \times 5.0$ \\
\hline$d_{13} \times t_{13}$ & $121 \times 8$ & $110.3 \times 3.9$ & $107.4 \times 3.6$ & $108 \times 4.0$ & $80.7 \times 4.9$ & $79.1 \times 5.6$ & $83 \times 5.0$ \\
\hline$d_{14} \times t_{14}$ & $102 \times 5$ & $89.2 \times 3.5$ & & & $89.4 \times 3.5$ & $87.7 \times 3.5$ & $95 \times 3.5$ \\
\hline$d_{15} \times t_{15}$ & $152 \times 8$ & $143.5 \times 5.2$ & $147.1 \times 5.1$ & & $133.5 \times 5.9$ & $135.1 \times 5.6$ & $133 \times 6.0$ \\
\hline$d_{16} \times t_{16}$ & $102 \times 5$ & $55.0 \times 3.5$ & & & $52.2 \times 3.5$ & $51.9 \times 3.5$ & $54 \times 3.5$ \\
\hline$d_{17} \times t_{17}$ & $180 \times 12$ & $112.8 \times 4.9$ & $116.3 \times 4.7$ & & $90.4 \times 6.1$ & $101.8 \times 5.4$ & $95 \times 6.0$ \\
\hline$d_{18} \times t_{18}$ & $180 \times 12$ & $143.5 \times 6.3$ & $147.1 \times 6.6$ & $152 \times 6.5$ & $148.1 \times 6.6$ & $143.3 \times 6.4$ & $146 \times 7.5$ \\
\hline$d_{19} \times t_{19}$ & $299 \times 10$ & $297.4 \times 9.9$ & $303.2 \times 10.1$ & $299 \times 10.0$ & $298.1 \times 9.9$ & $292.3 \times 9.7$ & $299 \times 10.0$ \\
\hline$d_{19} \times t_{20}$ & $299 \times 25$ & $297.4 \times 9.9$ & $303.2 \times 10.1$ & $299 \times 10.0$ & $298.1 \times 9.9$ & $292.3 \times 9.7$ & $299 \times 10.0$ \\
\hline$d_{21} \times t_{21}$ & $299 \times 25$ & $297.4 \times 21.0$ & $303.2 \times 21.1$ & $299 \times 22.0$ & $298.1 \times 22.3$ & $292.3 \times 22.3$ & $299 \times 24.0$ \\
\hline$d_{22} \times t_{22}$ & $102 \times 5$ & $89.2 \times 3.5$ & $90.9 \times 3.5$ & $95 \times 3.5$ & $89.4 \times 3.5$ & $87.7 \times 3.5$ & $95 \times 3.5$ \\
\hline$d_{23} \times t_{23}$ & $180 \times 12$ & $148.9 \times 5.3$ & $151.6 \times 5.3$ & $152 \times 5.5$ & $79.7 \times 11.4$ & $81.8 \times 10.6$ & $83 \times 1.2$ \\
\hline Weight, $\times 10^{3}, \mathrm{~kg}$ & \begin{tabular}{|l|}
30.78 \\
\end{tabular} & 18.45 & 18.98 & 19.70 & - & - & - \\
\hline Costs, UAH & 786681 & - & - & - & 534647 & 524257 & 552368 \\
\hline
\end{tabular}


Formulated parametric optimization problem for the steel lattice portal frame has been solved using software OptCAD. Mathematical apparatus of the software combines the finite element method to perform linear static analysis of the bar system, as well as improved gradient projection method to solve parametric optimization problems formulated as non-linear programming tasks $[19,20]$. Task dimensions are: account of design variables is 50 , account of problem constraints is 14000 .

Optimization results received using software OptCAD are presented by the Tables 5.1 and 5.2. Figure 5.1 show optimal design decision by the criterion of minimum structural weight of the steel lattice portal frame (project with start values of the design variables is indicated by the red color, optimum project is indicated by the blue color).

Conclusion. The results of the presented study can be formulated as follow:

1. The paper has proposed a mathematical model for parametric optimization problem of the steel lattice portal frame with CHS structural members. The design variable vector includes geometrical parameters of the structure (node coordinates), as well as cross-sectional dimensions of the structural members. The system of constraints covers load-carrying capacities constraints formulated for all design sections of structural members of the steel structure subjected to all ultimate load case combinations. The displacements constraints formulated for the specified nodes of the steel structure subjected to all serviceability load case combinations have been also included into the system of constraints. Additional requirements in the form of constraints on lower and upper values of the design variables, constraints on permissible minimal thicknesses, constraints on permissible maximum diameter-tothickness ratio for the structural members with circle hollow sections, as well as the conditions for designing gusset-less welded joints between structural members with circle hollow sections have been also considered in the scope of the mathematical model.

2. The method of the objective function gradient projection onto the active constraints surface with simultaneous correction of the constraints violations has been applied to solve the formulated parametric optimization problem.

3. A numerical algorithm for solving the parametric optimization problems of steel lattice portal frames with CHS structural members has been presented in the paper.

4. New optimal layouts of the steel lattice portal frame by the criterion of the minimum weight, as well as minimum costs on manufacturing and erection have been shown.

\section{REFERENCES}

1. Alpatov, $V$. The task of multi-criteria optimization of metal frame structures // MATEC Web of Conferences. - 2017. - No. 117. - No. 00007. DOI: 10.1051/matecconf/201711700007

2. Alpatov, V. Search for the Optimal Shape of Metal Spatial (space) Structures // IOP Conference Series: Materials Science and Engineering. - 2020. - Vol. 753. - No. 022050. DOI:10.1088/1757-899X/753/2/022050 
3. Kibkalo, A., Lebedeva, M., Volkov, M. Methods of parametric optimization of thin-walled structures and parameters which influence on it // MATEC Web of Conferences. - 2016. Vol. 53. - No. 01051. DOI: 10.1051/matecconf/20165301051

4. Alekseytsev, A.V. Frame structures optimization based on evolutionary modeling in active overall stability constraints // IOP Conf. Series: Journal of Physics: Conference Series. 2020. - No. 1425. - Article 012036. DOI:10.1088/1742-6596/1425/1/012036

5. Serpik, I. N., Alekseytsev, A. V. Optimization of steel frame building systems in terms of parameters and reliability requirements // IOP Conference Series: Materials Science and Engineering. - 2018. - Vol. 365. - No. 052003. DOI:10.1088/1757-899X/365/5/052003

6. Serpik, I. N., Averin, A. S. Optimization of steel frames with the choice of materials' grades with restrictions on general and local stability, strength and stiffness // IOP Conf. Series: Materials Science and Engineering. - 2020. - Vol. 913. - No. 022039. DOI:10.1088/1757$899 \mathrm{X} / 913 / 2 / 022039$.

7. Sergeyev, O. A., Kiselev, V. G., Sergeyeva, S. A. Overall instability and optimization of bar structures with random defects in case of constraints on faultless operation probability // Magazine of Civil Engineering. - 2013. - No. 44(9). - Pp. 30-41. DOI: 10.5862/MCE.44.4.

8. Permyakov, V. O., Yurchenko, V. V., Peleshko, I. D. An optimum structural computer-aided design using hybrid genetic algorithm // Proceeding of the International Conference "Progress in Steel, Composite and Aluminium Structures". - Taylor \& Francis Group. London, 2006. - Pp. 819-826.

9. Peleshko I., Yurchenko V. Parametric optimization of steel structures based on gradient projection method // Strength of Materials and Theory of Structures: Scientific-andtechnical collected articles. - Kyiv: KNUBA, 2020. - Issue 105. - P. 192-220. DOI: 10.32347/2410-2547.2020.105.192-220.

10. Yurchenko V.V., Peleshko I. D. Searching for optimal pre-stressing of steel bar structures based on sensitivity analysis // Archives of Civil Engineering. - 2020. - Vol. 66. - No. 3. Pp. 525-540. DOI: $10.24425 /$ ACE.2020.134411

11. Kuci, E., Henrotte, F., Duysinx, P., Geuzaine, C. Design sensitivity analysis for shape optimization based on the Lie derivative // Computer methods in applied mechanics and engineering. - 2017. - Vol. 317. - Pp. 702-722. DOI: 10.1016/j.cma.2016.12.036

12. SP 16.13330.2017, Steel structures. Moscow: Minstroy, 2017. 140 p. (rus)

13. Huebner, K. H., Dewhirst, D. L., Smith, D. E., Byrom, T. G. The finite element method for engineers. 4th ed. John Wiley \& Sons, 2001.744 p.

14. Peleshko, I. D., Yurchenko, V. V. Improved gradient projection method for parametric optimization of bar structures // Magazine of Civil Engineering. - 2020. - № 98(6). Article No. 9812. DOI: 10.18720/MCE.98.12.

15. Peleshko I., Yurchenko $V$. An improved gradient-based method to solve parametric optimisation problems of the bar structures // Strength of Materials and Theory of Structures: Scientific-and-technical collected articles. - 2020. - Issue 104. - Pp. 265-288. DOI: $10.32347 / 2410-2547.2020 .104 .265-288$.

16. Haug, E. J., Arora, J. S. Applied optimal design: mechanical and structural systems. - John Wiley \& Sons, 1979. $-520 \mathrm{p}$.

17. Reklaitis, G. V., Ravindran, A., Ragsdell, K. M. Engineering optimization. Methods and applications. - Wiley, 2006. -688 p.

18. Wilkinson J. H., Reinsch C. Handbook for Automatic Computation. Volume II: Linear Algebra. - Heidelberg New York Springer-Verlag Berlin. 1971. 441 p. DOI: $10.1137 / 1014116$

19. Peleshko I. D., Yurchenko V. V., Beliaev N. A. Computer-aided design and optimization of steel structural systems // Zeszyty naukowe Politechniki Rzeszowskiej "Budownictwo i inżynieria środowiska". - 2009. - Nr. 264. - z. 52. Pp. 145-154.

20. Peleshko I. D., Yurchenko V. V., Beliaev N. A. Computer-aided design and optimization of steel structural systems // Proceedings of XII International Scientific Conference "Current issues of civil and environmental engineering” Rzeszów-Lviv-Kosice. - 2009. - P. 49. 
УдК $624.04,519.853$

Юрченко В.В., Пелешко І.Д.

ПАРАМЕТРИЧНА ОПТИМІЗАЦІЯ СТАЛЕВОЇ РЕШІТЧАСТОЇ РАМИ 3 НЕСУЧИМИ ЕЛЕМЕНТАМИ ІЗ КРУГЛИХ ТРУБ

У статті запропонована математична модель для задачі параметричної оптимізації сталевої решітчастої поперечної рами каркасу будівлі, несучі елементи якої виконані 3 круглих труб. Вектор змінних проектування містить геометричні параметри конструкції (координати вузлів), а також розміри поперечних перерізів несучих елементів конструкції. Система обмежень охоплює обмеження несучої здатності, сформульовані для усіх розрахункових перерізів елементів конструкції, що підлягає дії усіх комбінацій навантажень першої групи граничних станів. До системи обмежень також залучені обмеження переміщень вузлів, сформульовані для визначених вузлів конструкції, що підлягає дії усіх комбінацій навантажень другої групи граничних станів. Додаткові обмеження у формі обмежень на верхню та нижню межі варіювання змінних проектування, обмеження на допустиму мінімальну товщину перерізу, обмеження на допустиме максимальне відношення діаметру до товщини труби, а також умови конструювання безфасонкових вузлів решітчастої конструкції з елементами із круглих труб також були розглянуті у складі системи обмежень математичної моделі. Для розв'язку сформульованої задачі параметричної оптимізації використовувався метод проекції градієнту функції мети на поверхню активних обмежень за одночасної ліквідації нев'язок у порушених обмеженнях. Як результат отримані нові оптимальні проектні рішення сталевої решітчастої поперечної рами за критерієм мінімуму маси конструкції, а також за критерієм мінімуму кошторисної вартості ії виготовлення та зведення.

Ключові слова: оптимізація, сталева решітчаста рама, нелінійне програмування, міцність, стійкість, жорсткість, градієнтний метод, метод скінченних елементів, числовий алгоритм.

UDC $624.04,519.853$

Yurchenko V.V., Peleshko I.D.

PARAMETRIC OPTIMIZATION OF STEEL LATTICE PORTAL FRAME WITH CHS STRUCTURAL MEMBERS

The paper has proposed a mathematical model for parametric optimization problem of the steel lattice portal frame. The design variable vector includes geometrical parameters of the structure (node coordinates), as well as cross-sectional dimensions of the structural members. The system of constraints covers load-carrying capacities constraints formulated for all design sections of structural members of the steel structure subjected to all ultimate load case combinations. The displacements constraints formulated for the specified nodes of the steel structure subjected to all serviceability load case combinations have been also included into the system of constraints. Additional requirements in the form of constraints on lower and upper values of the design variables, constraints on permissible minimal thicknesses, constraints on permissible maximum diameter-to-thickness ratio for the structural members with circle hollow sections, as well as the conditions for designing gusset-less welded joints between structural members with circle hollow sections have been also considered in the scope of the mathematical model. The method of the objective function gradient projection onto the active constraints surface with simultaneous correction of the constraints violations has been used to solve the formulated parametric optimization problem. New optimal layouts of the steel lattice portal frame by the criterion of the minimum weight, as well as minimum costs on manufacturing and erection have been presented.

Keywords: optimization, steel lattice frame, nonlinear programming, strength, buckling, stiffness, gradient projection method, finite element method, numerical algorithm.

УДК $624.04,519.853$

Юрченко В.В., Пелешко И.Д.

ПАРАМЕТРИЧЕСКАЯ ОПТИМИЗАЦИЯ СТАЛЬНОЙ РЕШЕТЧАТОЙ РАМЫ С НЕСУЩИМИ ЭЛЕМЕНТАМИ ИЗ КРУГЛЫХ ТРУБ

В статье предложена математическая модель для задачи параметрической оптимизации стальной решетчатой поперечной рамы каркаса здания, несущие элементы которой выполнены из круглых труб. Вектор переменных проектирования содержит геометрические параметры конструкции (координаты узлов), а также размеры поперечных сечений несущих элементов конструкции. Система ограничений включает ограничения несущей способности, сформулированные для всех расчетных сечений элементов конструкции, 
подлежащей действию всех комбинаций нагрузок первой группы предельных состояний. В систему ограничений также включены ограничения перемещений узлов, сформулированные для определенных узлов конструкции, подлежащей действию всех комбинаций нагрузок второй группы предельных состояний. Дополнительные ограничения в форме ограничений на верхнюю и нижнюю границы варьирования переменных проектирования, ограничения на допустимую минимальную толщину сечения, ограничения на допустимое максимальное отношение диаметра к толщине трубы, а также условия конструирования бесфасоночных узлов решетчатой конструкции с элементами их круглых труб также были рассмотрены в составе системы ограничений математической модели. Для решения сформулированной задачи параметрической оптимизации использовался метод проекции градиента функции цели на поверхность активных ограничений при одновременной ликвидации невязок в нарушенных ограничениях. В результате получены новые оптимальные проектные решения стальной решетчатой поперечной рамы по критерию минимума массы конструкции, а также по критерию минимума сметной стоимости на ее изготовление и возведение.

Ключевые слова: оптимизация, стальная решетчатая рама, нелинейное программирование, прочность, устойчивость, жесткость, градиентный метод, метод конечных элементов, численный алгоритм.

\section{УДК $624.04,519.853$}

Юрченко В.В., Пелешко І.Д. Параметрична оптимізація сталевої решітчастої рами 3 несучими елементами із круглих труб // Опір матеріалів і теорія споруд: наук.-тех. збірн. - К.: КНУБА, 2021. - Вип. 107. - С. 45-74.

У статті запропонована математична модель для задачі параметричної оптимізації сталевої решітчастої поперечної рами каркасу будівлі, несучі елементи якої виконані $з$ круглих труб. Як вектор змінних проектування розглянуто координати вузлів конструкиії, а також розміри поперечних перерізів ї̈ несучих елементів. Система обмежень охоплювала обмеження несучої здатності стержневих елеметів конструкиї, обмеження переміщень ї̈ вузлів, обмеження на допустиму мінімальну товщину перерізу, обмеження на допустиме максимальне відношення діаметру до товщини труби, а також нерівності, що описують умови конструювання безфасонкових вузлів решітчастої конструкиії з елементами із круглих труб. Для розв'язку сформульованої задачі використовувався метод проекції градієнту функиії мети на поверхню активних обмежень за одночасної ліквідації нев'язок у порушених обмеженнях. Як результат отримані нові оптимальні проектні рімення сталевої решітчастої поперечної рами за критерісм мінімуму маси конструкції, а також за критерієм мінімуму кошторисної вартості ї̈ виготовлення та зведення.

Іл. 5. Табл. 3. Бібліог. 20 назв.

\section{УДК $624.04,519.853$}

Yurchenko V. V., Peleshko I. D. Parametric optimization of steel lattice portal frame with chs structural members // Strength of Materials and Theory of Structures: Scientific-and-technical collected articles - Kyiv: KNUBA, 2021. - Issue 107. - P. 45-74.

The paper has proposed a mathematical model for parametric optimization problem of the steel lattice portal frame. The design variable vector has included node coordinates of the structure, as well as cross-sectional dimensions of the structural members. The system of constraints has covered load-carrying capacities constraints for structural members, the displacements constraints for specified structural nodes, constraints on permissible minimal thicknesses, constraints on permissible maximum diameter-to-thickness ratio for the structural members with circle hollow sections, as well as the conditions for designing gusset-less welded joints between structural members with circle hollow sections. The method of the objective function gradient projection onto the active constraints surface with simultaneous correction of the constraints violations has been used to solve the formulated problem. New optimal layouts of the steel lattice portal frame by the criterion of the minimum weight, as well as minimum costs on manufacturing and erection have been presented.

Figs. 5. Tabs. 3. Refs. 20. 


\section{УДК $624.04,519.853$}

Юрченко В. В., Пелешко И. Д. Параметрическая оптимизация стальной решетчатой рамы с несущими элементами из круглых труб // Сопротивление материалов и теория сооружений: науч.- тех. сборн. - К.: КНУСА, 2021. - Вып. 107. - С. 45-74.

B статье предложена математическая модель для задачи параметрической оптимизации стальной решетчатой поперечной рамы каркаса здания, несущие элементы которой выполнены из круглых труб. В качестве вектора переменных проектирования рассматривались координаты узлов конструкции, а такәе размеры поперечных сечений ее несущих элементов. Система ограничений охватывала ограничения несущей способности элементов конструкции, ограничения перемещений выбранных узлов конструкции, ограничения на допустимую минимальную толщину сечения, ограничения на допустимое максимальное отношение диаметра к толщине трубы, а также условия конструирования бесфасоночных узлов решетчатой конструкиии с элементами их круглых труб. Для решения сформулированной задачи использовался метод проекиии градиента функции цели на поверхность активных ограничений при одновременной ликвидачии невязок 6 нарушенных ограничениях. В результате получены новые оптимальные проектные решения стальной решетчатой поперечной рамы по критерию минимума массы конструкции, а также по критерию минимума сметной стоимости на ее изготовление и возведение.

Ил. 5. Табл. 3. Библиог. 20 назв.

Автор: доктор технічних наук, професор кафедри металевих та дерев'яних конструкцій Юрченко Віталіна Віталіївна

Адреса робоча: 03680 Украӥна, м. Київ, Повітрофлотський пр. 31, Київський начіональний університет будівниитва і архітектури

Робочий тел.: +38(044)249-71-91

Мобільний тел.: +38(063)89-26-491

E-mail: vitalina@scadsoft.com

SCOPUS ID: 25637856200

ORCID ID: https://orcid.org/0000-0003-4513-809X

Автор: кандидат технічних наук, доцент кафедри будівельного виробництва Пелешко Іван Дмитрович

Адреса робоча: 79013 Украӥна, м. Львів, вул. Ст. Бандери 12, Національний університет «Львівська політехніка»

Робочий тел.: +38 (032) 258-25-41

Мобільний тел.: +38(098)41-57-517

E-mail: ipeleshko@polynet.lviv.ua

SCOPUS ID: 25637832500

ORCID ID: https://orcid.org/0000-0001-7028-9653 